\title{
Tropical eels Anguilla spp. recruiting to Réunion Island in the Indian Ocean: taxonomy, patterns of recruitment and early life histories
}

\author{
Tony Robinet ${ }^{1}$, Raymonde Lecomte-Finiger ${ }^{2, *}$, Karine Escoubeyrou $^{2,3}$, \\ Eric Feunteun ${ }^{1}$ \\ ${ }^{1}$ Laboratoire de Biologie et Environnement Marins, EA 3168, Université de La Rochelle, Avenue Michel Crépeau, \\ 17000 La Rochelle, France \\ ${ }^{2}$ Laboratoire d'Ichtyoécologie Tropicale et Méditerranéenne, EPHE, CNRS, UMR 8046, Université de Perpignan, \\ 50 Avenue de Villeneuve, 66860 Perpignan cedex, France \\ ${ }^{3}$ Present address: Observatoire Océanologique, Laboratoire ARAGO, UMR 7621, Université Paris VI, \\ 66651 Banyuls-sur-mer cedex, France
}

\begin{abstract}
Anguillid glass eels were sampled between October 2000 and October 2001 in an estuarine goby-fry traditional fishery of Réunion Island $\left(21^{\circ} \mathrm{S}, 56^{\circ} \mathrm{E}\right)$, Mascarene Islands, western Indian Ocean. Recruitment occurred from November to April. Among the 633 specimens collected, 4 species were identified by biometric measurements coupled with number of vertebrae $(61.9 \%$ of the specimens were Anguilla marmorata, $19.4 \%$ A. bicolor bicolor, $18.3 \%$ A. mossambica and $0.3 \%$ A. nebulosa labiata). A. mossambica had the shortest total length at recruitment $(51.2 \pm 2.7 \mathrm{~mm})$, compared to A. marmorata $(53.3 \pm 2.5 \mathrm{~mm})$ and A. bicolor bicolor $(54.0 \pm 2.1 \mathrm{~mm})$. Most juvenile pigmentation corresponded to the glass eel stage (VA to VB). We extracted 34 otoliths and visualized their microstructure by SEM. The short-finned A. bicolor bicolor had the shortest leptocephalus stage $(46.2 \pm 5.8 \mathrm{~d})$ and age at recruitment $(79.8 \pm 7.7 \mathrm{~d})$. The long-finned glass eels had the same age at recruitment (120.2 \pm 24.7 and $123.6 \pm 17 \mathrm{~d}$ for $A$. marmorata and A. mossambica respectively) and the same leptocephalus stage duration $(96.9 \pm 26.4$ and $102.1 \pm 17.2 \mathrm{~d}$ for A. marmorata and A. mossambica respectively). Otolith readings and sampling dates showed that $A$. mossambica hatched about 2 mo earlier than A. marmorata. Their identical early life histories should imply adjoining spawning grounds, whereas $A$. bicolor bicolor must spawn in a distinctive location. Hypotheses for spawning area locations are discussed as a function of the region's oceanic circulation.
\end{abstract}

KEY WORDS: Anguilla spp. - Indian Ocean · Réunion Island · Migration · Otoliths · Recruitment age Resale or republication not permitted without written consent of the publisher

\section{INTRODUCTION}

The genus Anguilla comprises 15 species distributed around the world (Castle \& Williamson 1974). In the Indian Ocean, 4 species have been reported (Ege 1939), namely Anguilla bicolor bicolor McClelland (1844), A. marmorata Quoy \& Gaimard (1824), A. mossambica Peters (1852) and A. nebulosa labiata McClelland (1844). The long-finned eels A. mossambica and $A$. nebulosa labiata occur exclusively on the
East African coast and in the Mascarene Islands (Ege 1939, Jubb 1961), while the short-finned eel A. bicolor bicolor occurs throughout the Indian Ocean, from the western part of the African continent and islands (Ege 1939, Jespersen 1942, Frost 1957, Jubb 1961, Castle 1984, 1986, Marquet et al. 1997) to eastern Asia (Indian coast, Malaysia, Sumatra, Java) and NW Australia (Ege 1939, Arai et al. 1999a). The long-finned mottled A. marmorata is the most widely distributed eel species, occurring from the SE African coast to the Japan- 
ese archipelago and Polynesia (Ege 1939, Nishi \& Imai 1969, Marquet \& Lamarque 1986, Jellyman 1987, Marquet \& Galzin 1991, Williamson \& Boëtius 1993, Budimawan 1997, Marquet et al. 1997, Arai et al. 2002). Substantial knowledge on the ecological aspects of these anguillid eels is limited. The biological data available cover taxonomic features, distribution area and ecology of sub-adult stages (Ege 1939, Frost 1957, van Someren \& Whitehead 1959, Jubb 1961, 1964, Tesch 1977, Bruton et al. 1987, Marquet et al. 1997, Keith et al. 1999). Little is known about glass eels recruiting in rivers of the western Indian Ocean (see Table 3). Glass eel recruitment has been described for A. marmorata subpopulations in Indonesia, the Philippines and Polynesia (Tabeta et al. 1987, Budimawan 1997, Arai et al. 1999ab, Sugeha et al. 2001a), and for A. bicolor bicolor in Indonesia (Arai et al. 1999a). For the western Indian Ocean area, only Ege (1939) and Frost (1957) have described the morphology, meristic characters and tail pigmentation of the glass eels $A$. marmorata and $A$. nebulosa labiata, and since then no study has been made and no data is available on young stages of anguillid eels in the western Indian Ocean. This study presents an original otolimetric dataset on glass eels recruiting in the oceanic area to the east of Madagascar, that will serve as a basis for further research on anguillid eel ecology in this area. Glass eels were regularly collected over a period of $1 \mathrm{yr}$ from a traditional goby-fry fishery, at a river mouth on Réunion Island. We define the recruitment patterns, describing species composition, body size and pigmentation stages. Early life histories were determined by otolith microstructure analysis. The present state of knowledge on anguillid eel reproduction in the Indian Ocean is discussed.

\section{MATERIALS AND METHODS}

Sampling protocol. Réunion Island $\left(21^{\circ} \mathrm{S}, 56^{\circ} \mathrm{E}\right.$, Fig. 1) is a recent volcanic formation in the SW Indian Ocean, $700 \mathrm{~km}$ from East Madagascar and $170 \mathrm{~km}$ from Mauritius. In the estuary of the Roches River (a small catchment, $24.5 \mathrm{~km}^{2}$, on the eastern coast), a fyke-net was settled at the river mouth, facing the sea, $4 \mathrm{~m}$ distant from the right bank and $100 \mathrm{~m}$ from oceanic waters. The net was a traditional trap used in goby-fry (Sicyopterus lagocephalus) fishery, and comprised a mesh cone with the wide mouth facing downstream and leading upriver-migrating fishes into a removable collection chamber. Glass eels were collected from October 2000 to October 2001. Sampling was not quantitative, since the net was set by goby fishermen, who gave priority to those goby larvae exploited commercially during the traditional fishing season, from November to February. The goby traditional fishery is limited to 4 to $5 \mathrm{~d}$ around the new moon, and coincides with the rainy warm season. Sampling was also carried outside this traditional fishery period, with the same sampling pattern, i.e. 1 net during 1 night at new

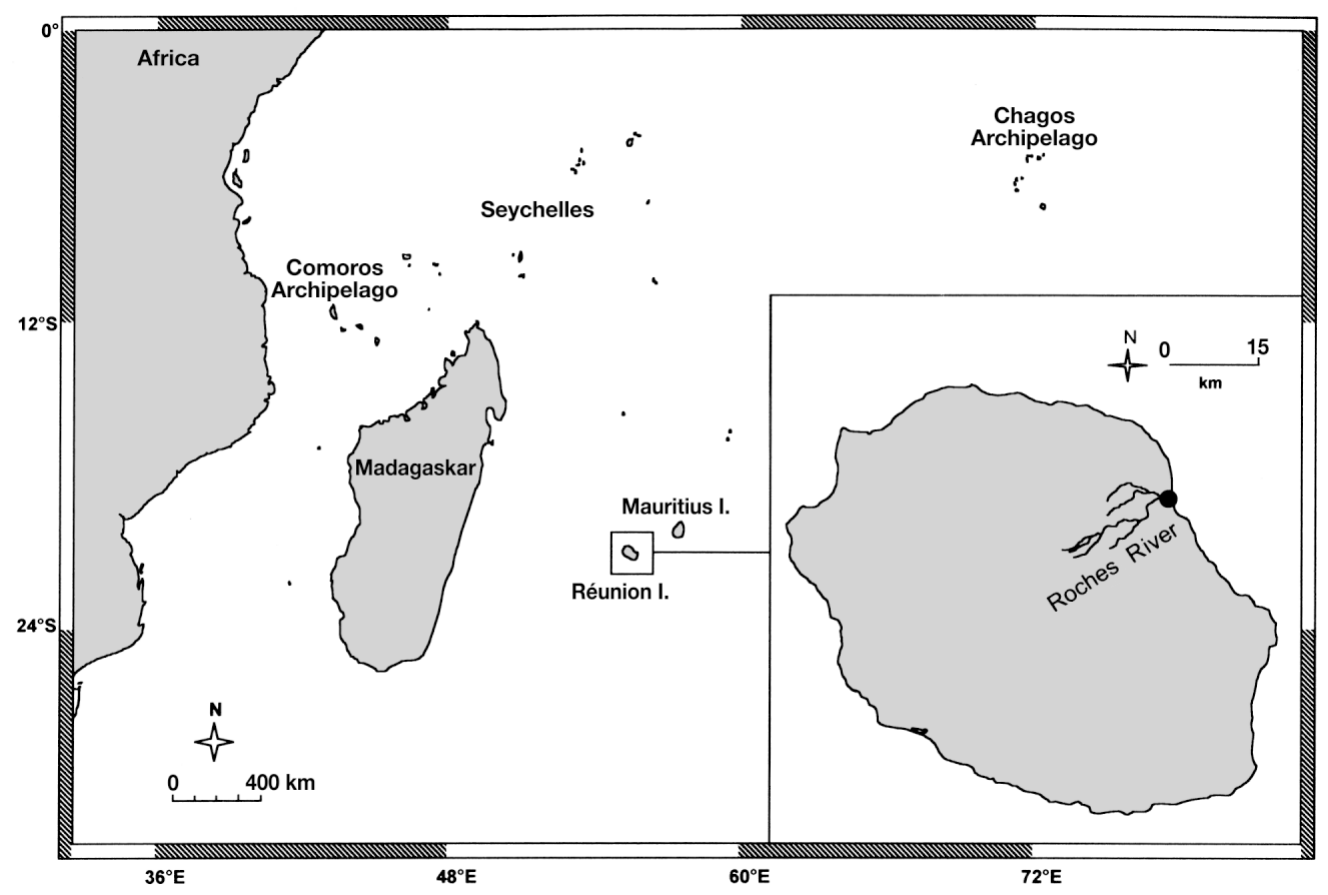

Fig. 1. Location of Réunion Island in the Indian Ocean and of sampling estuary ( 
moon. Glass eels were collected without regard to species in order to maintain a standard qualitative sampling throughout the recruitment period. All specimens were preserved in $90 \%$ ethanol.

Species determination. Eel identification was based on characters previously defined by Ege (1939), Marquet (1992) and Budimawan (1997). Morphological criteria (total length and distance between the origins of the dorsal and anal fins to the nearest $0.5 \mathrm{~mm}$ as percent total length) and caudal pigmentation were both used (Elie et al. 1982, Marquet 1992, Budimawan 1997). Pigmentation was recorded for 2 parts of the body (head and tail), and was classified as VA (no pigmentation) to VIB (fully pigmented) according to conventional classification (Elie et al. 1982). The caudal cutaneous pigmentation facilitated identification. All caudal parts of the glass eels were digitalized on a video image-analysis system (Visilog-Noesis). Vertebrae were counted by micro-X-ray (Sigma 2060) on a subsample $(\mathrm{n}=46)$ of glass eels with no characteristic tail pigmentation.

Otolith preparation and examination. In order to represent the entire recruitment period by species as well as possible, we selected 34 specimens for analysis otolith microstructures. Otoliths were extracted and cleaned. For microstructure analysis, otoliths were embedded in metacrylate resin, ground with 1000 and $5 \mu \mathrm{m}$ grit paper until the nucleus was visible, then etched with $5 \%$ EDTA solution, and coated with gold $(10 \mathrm{~nm})$ before examination with a SEM scanning electron miscrospe (Hitachi S-520) at various magnifications. Using SEM microphotographs of otolith sections, different patterns were identified in accordance with conventional characteristics established for other eel species (primordium and core, first feeding-check, leptocephalus zone, metamorphosis zone, and transition mark to freshwater: see Castonguay 1987, Tabeta et al. 1987, Umezawa et al. 1989, Tsukamoto \& Umezawa 1990, Lecomte-Finiger 1992, Tzeng \& Tsai 1992). Wider growth increments that have been interpreted by previous authors to occur in association with metamorphosis were used to separate the Leptocephalus zone from the metamorphosis zone. Since Umezawa et al. (1989), Arai et al. (2000) and Sugeha et al. (2001b) established that otolith increment-deposition occurs daily in Anguilla japonica, A. celebesensis and A. marmorata, the number of these increments for the oceanic larval stages were counted from the first feedingcheck to the freshwater recruitment-check (when present). The resulting number of increments was interpreted as the duration of marine life (LecomteFiniger 1992, 1994). The duration of larval stages, age at recruitment and hatching date were counted for each otolith, and means $( \pm \mathrm{SD})$ were calculated for each species. A Kruskal-Wallis (K-W) ANOVA non- parametric rank test (Kruskal \& Wallis 1952) was used to test the significance of differences between the early life histories and sizes between species, followed by pairwise comparisons (Student's $t$-test). The Kolmogorov-Smirnov test, K-S (Sokal \& Rohlf 1981), designed to test differences in the general shapes of the distributions in 2 samples, was used to assess differences in the timing of recruitment among glass eels species.

\section{RESULTS}

\section{Species composition and recruitment patterns}

Tail pigmentation and morphology allowed us to separate 3 glass eels species: Anguilla bicolor bicolor McClelland (1844) A. marmorata Quoy \& Gaimard (1824), and Anguilla mossambica Peters (1868). Each of these species had a specific caudal pigmentation (Fig. 2). Body measurements (ano-dorsal length as \%
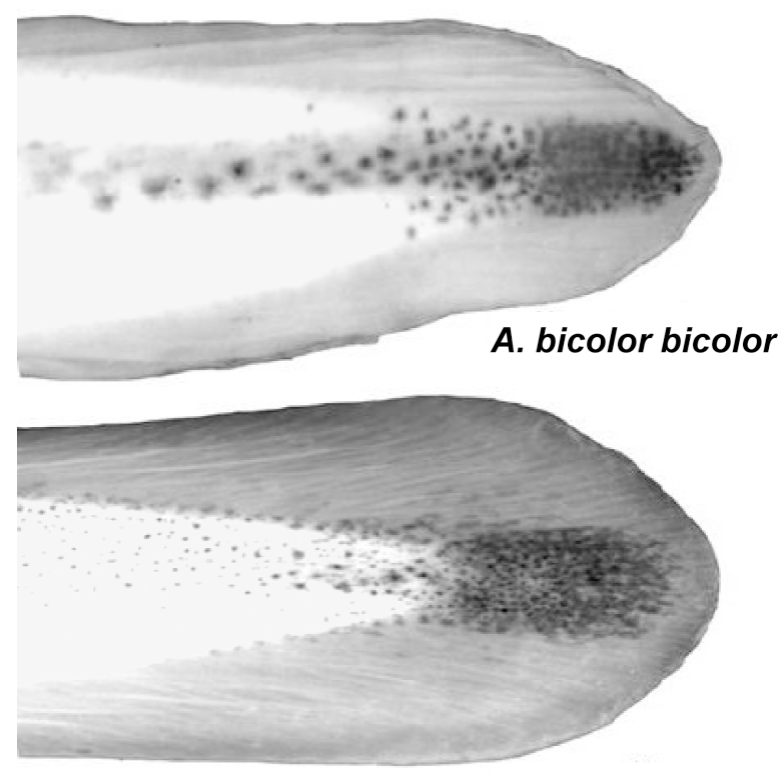

A. mossambica

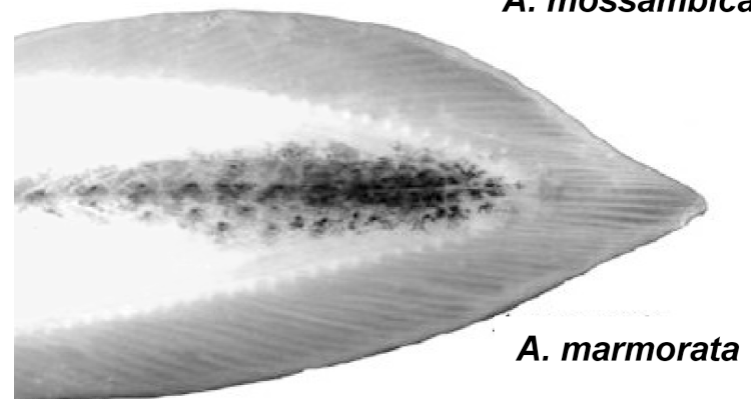

Fig. 2. Anguilla spp. Specific pigmentation of tails of glass eels 
Table 1. Anguilla spp. Pigmentation stage, number of specimens, and measurements of morphological characters in glass eels collected from Roches River, Réunion Island. Pigmentation was classified from VA (no pigmentation) to VIB (fully pigmented). n: number of glass eels and elvers collected; AL: anal length; DL: dorsal length; TL: total length

\begin{tabular}{|c|c|c|c|c|c|}
\hline \multirow{2}{*}{$\begin{array}{l}\text { Species } \\
\quad \text { Pigmentation stage }\end{array}$} & \multirow[t]{2}{*}{$\mathrm{n}$} & \multicolumn{2}{|c|}{ Length (mm) } & \multirow{2}{*}{$\begin{array}{c}\text { Mean \% } \\
(\mathrm{AL}-\mathrm{DL}) / \mathrm{TL}\end{array}$} & \multirow{2}{*}{$\begin{array}{l}\text { Relative frequency } \\
(\%)\end{array}$} \\
\hline & & Mean \pm SD & Range & & \\
\hline \multicolumn{6}{|l|}{ A. bicolor bicolor } \\
\hline VA & 53 & $54.7 \pm 2.1$ & $48.0-59.0$ & 1.8 & 43.1 \\
\hline VB & 63 & $53.6 \pm 1.9$ & $50.0-58.0$ & 1.9 & 51.2 \\
\hline VIA2 & 3 & $54.2 \pm 1.6$ & $53.0-56.0$ & 2.2 & 2.4 \\
\hline VIA3 & 3 & $50.3 \pm 1.2$ & $49.0-51.0$ & 1.3 & 2.4 \\
\hline VIA4 & 1 & 52.0 & - & 1.0 & 0.8 \\
\hline Total & 123 & $54.0 \pm 2.1$ & $48.0-59.0$ & - & - \\
\hline \multicolumn{6}{|l|}{ A. marmorata } \\
\hline VA & 111 & $54.2 \pm 2.0$ & $48.0-58.5$ & 16.6 & 28.3 \\
\hline VB & 226 & $53.5 \pm 2.4$ & $46.5-58.5$ & 16.7 & 57.7 \\
\hline VIA0 & 5 & $51.6 \pm 2.4$ & $48.5-55.0$ & 15.7 & 1.3 \\
\hline VIA1 & 22 & $50.7 \pm 2.6$ & $45.5-55.0$ & 16.6 & 5.6 \\
\hline VIA2 & 19 & $50.9 \pm 1.7$ & $48.0-54.0$ & 16.5 & 4.8 \\
\hline VIA3 & 3 & $50.3 \pm 4.0$ & $48.0-55.0$ & 17.6 & 0.8 \\
\hline VIA4 & 6 & $49.0 \pm 1.1$ & $48.0-51.0$ & 16.0 & 1.5 \\
\hline Total & 392 & $53.3 \pm 2.5$ & $45.5-58.5$ & - & - \\
\hline \multicolumn{6}{|l|}{ A. mossambica } \\
\hline VA & 13 & $52.4 \pm 2.6$ & $48.0-56.5$ & 12.4 & 11.2 \\
\hline VB & 68 & $51.4 \pm 2.7$ & $40.5-56.0$ & 13.4 & 58.6 \\
\hline VIA0 & 9 & $51.2 \pm 2.3$ & $48.0-55.5$ & 13.2 & 7.8 \\
\hline VIA1 & 7 & $52.3 \pm 2.9$ & $49.5-57.0$ & 14.9 & 6.0 \\
\hline VIA2 & 6 & $52.25 \pm 1.7$ & $48.0-52.5$ & 12.4 & 5.2 \\
\hline VIA3 & 3 & $50.7 \pm 2.9$ & $49.0-54.0$ & 16.3 & 2.6 \\
\hline VIA4 & 9 & $48.4 \pm 1.5$ & $46.0-51.0$ & 17.0 & 7.8 \\
\hline VIB & 1 & 47.0 & - & 14.9 & 0.9 \\
\hline Total & 116 & $51.2 \pm 2.7$ & $40.5-57.0$ & - & - \\
\hline \multicolumn{6}{|l|}{ A. nebulosa labiata } \\
\hline VB & 2 & 51.8 & $51.0-52.5$ & 15.0 & - \\
\hline
\end{tabular}

total length, Table 1) were: 1.0 to $2.0 \%$ for $A$. bicolor bicolor, 15.7 to $17.6 \%$ for A. marmorata and 12.4 to $17.0 \%$ for A. mossambica. After coupling body measurements and tail pigmentation, the identity of only

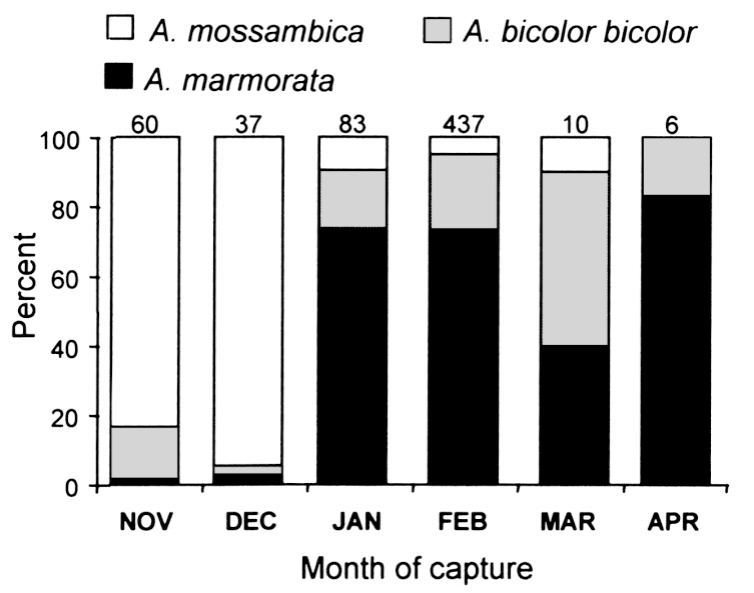

Fig. 3. Anguilla spp. Recruitment of glass eels collected during goby-fry fishery from November 2000 to April 2001 in Roches River, Réunion Island
46 specimens was doubtful. Morphological criteria classified these as A. mossambica, but their caudal pigmentation was unusual. We therefore classified these glass eels by vertebrae counts, which identified them as A. mossambica, with the exception of 2 speciemens with 111 vertebrae, which were classified as A. nebulosa labiata Peters (1852).

A total of 633 specimens were collected. Species were unequally represented. Most specimens were Anguilla marmorata (61.9\%) followed by $A$. bicolor bicolor (19.4\%) and A. mossambica (18.3\%), while $A$. nebulosa labiata was represented by only 2 specimens $(0.3 \%)$.

Although the glass eel trapping began in early October 2000, the first glass eel was not collected until 21 November 2000. The last specimen was collected on 26 April 2001. The species composition during the goby fishery season 2000 to 2001 varied between November/December and March/April (Fig. 3). No glass eels were collected from May 2001 to October 2001 (end of sampling). All 3 main species were present at least 5 mo in the year: Anguilla marmorata and A. bicolor bicolor were present throughout almost the whole 
sampling period; A. mossambica occurred from November to March, and more specimens were collected at the end of November to early December. A. mossambica seemed to arrive first in the sampling area, although this was not confirmed by statistical tests (K-S: number of specimens collected per week and per species; $\mathrm{p}>0.05$ ).

\section{Size and pigmentation}

Table 1 gives the mean length of each species at each pigmentation stage. Anguilla mossambica was significantly smaller $(51.2 \pm 2.7 \mathrm{~mm})$ than $A$. bicolor bicolor $(54.0 \pm 2.1 \mathrm{~mm})$ and A. marmorata $(53.3 \pm$ $2.5 \mathrm{~mm}$ ). Length differed significantly between $A$. marmorata and A. bicolor bicolor also (K-W for all species, $\mathrm{p}<0.001$; paired $t$-test, $\mathrm{p}<0.001$ between all species; Fig. 4). Most of the 633 specimens caught immediately upon entering freshwater from the ocean were glass eels in transparent stages (VA, VB, VIA0; Table 1), i.e. the first 'continental' stages. In all species, length declines as pigmentation progresses.

\section{Otolith microstructure analysis}

The duration of larval stages, otolith growth rates, ages at recruitment and hatching dates are listed in Table 2. Otolith microstructures are presented in Fig. 5. Oceanic early life in Anguilla bicolor bicolor $(79.8 \pm$ $0.7 \mathrm{~d})$ was significantly shorter than in $A$. marmorata $(120.2 \pm 24.7 \mathrm{~d})$ and A. mossambica $(123.6 \pm 17 \mathrm{~d}, \mathrm{~K}-\mathrm{W}$, $\mathrm{p}<0.001$ and paired $t$-test, $\mathrm{p}<0.001$ ). The leptocephalus stage $(46.2 \pm 5.8 \mathrm{~d})$ of $A$. bicolor bicolor was markedly shorter than that of the other species $(\mathrm{K}-\mathrm{W}$,
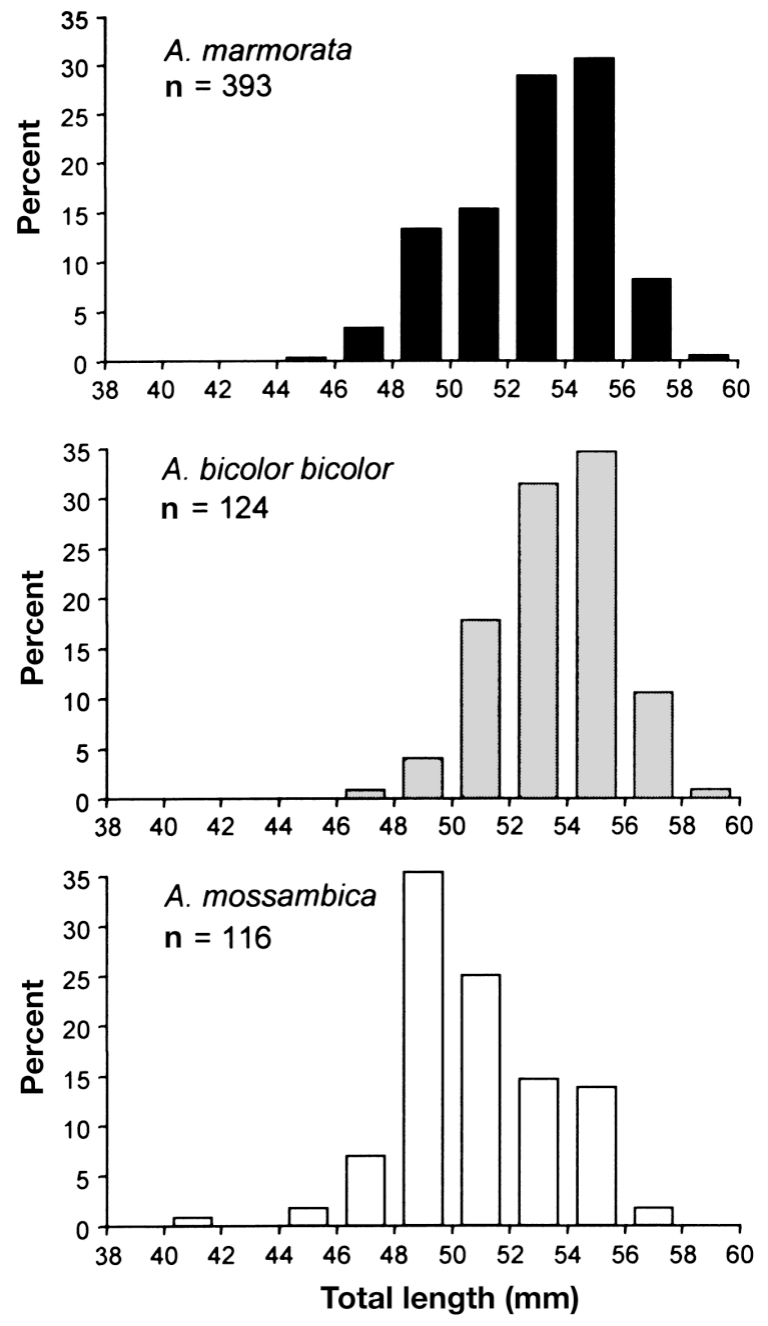

Fig. 4. Anguilla spp. Length-frequency distribution of glass eels collected during goby-fry fishery in Roches River, Réunion Island

Table 2. Anguilla spp. Otolith microstructure analysis and otolith growth rates of glass eels collected from Roches River, Réunion Island

\begin{tabular}{|c|c|c|c|c|c|}
\hline & & A. bicolor bicolor & A. marmorata & A. mossambica & A. nebulosa labiata \\
\hline \multicolumn{2}{|c|}{$\mathrm{N}$ glass eels age determined } & 11 & 9 & 12 & 2 \\
\hline \multirow[t]{2}{*}{ Leptocephalus } & Duration (d) & $\begin{array}{c}46.2 \pm 5.8 \\
(39-57)\end{array}$ & $\begin{array}{c}96.9 \pm 26.4 \\
(60-135)\end{array}$ & $\begin{array}{c}102.1 \pm 17.2 \\
(72-130)\end{array}$ & $\begin{array}{c}117.5 \pm 3.5 \\
(115-120)\end{array}$ \\
\hline & Otolith growth rate $\left(\mu \mathrm{m} \mathrm{d}^{-1}\right)$ & $\begin{array}{l}0.9 \pm 0.2 \\
(0.6-1.2)\end{array}$ & $\begin{array}{l}0.7 \pm 0.1 \\
0.5-0.8)\end{array}$ & $\begin{array}{l}0.7 \pm 0.1 \\
(0.6-1.0)\end{array}$ & $\begin{array}{l}0.6 \pm 0.0 \\
(0.5-0.6)\end{array}$ \\
\hline \multirow[t]{2}{*}{ Metamorphosis } & Duration (d) & $\begin{array}{c}33.6 \pm 7.5 \\
(24-48)\end{array}$ & $\begin{array}{c}23.3 \pm 4.5 \\
(14-29)\end{array}$ & $\begin{array}{c}21.5 \pm 4.5 \\
(15-28)\end{array}$ & $\begin{array}{c}26.5 \pm 2.1 \\
(25-28)\end{array}$ \\
\hline & Otolith growth rate $\left(\mu \mathrm{m} \mathrm{d}^{-1}\right)$ & $\begin{array}{l}2.0 \pm 0.5 \\
(1.4-3.2)\end{array}$ & $\begin{array}{l}2.3 \pm 0.6 \\
(1.7-3.4)\end{array}$ & $\begin{array}{l}2.4 \pm 0.5 \\
(1.4-3.3)\end{array}$ & $\begin{array}{l}1.8 \pm 0.5 \\
(1.5-2.2)\end{array}$ \\
\hline \multicolumn{2}{|c|}{ Age at recruitment $(d)$} & $\begin{array}{c}79.8 \pm 7.7 \\
(68-96)\end{array}$ & $\begin{array}{c}120.2 \pm 24.7 \\
(86-160)\end{array}$ & $\begin{array}{c}123.6 \pm 17.0 \\
(96-151)\end{array}$ & $\begin{array}{c}144.0 \pm 1.4 \\
(143-145)\end{array}$ \\
\hline \multicolumn{2}{|l|}{ Hatching date } & $\begin{array}{c}\text { Sep 13, 2000- } \\
\text { Jan 18, } 2001\end{array}$ & $\begin{array}{l}\text { Sep 6, 2000- } \\
\text { Dec 22, } 2000\end{array}$ & $\begin{array}{l}\text { Jul } 15,2000- \\
\text { Oct } 22,2000\end{array}$ & $\begin{array}{l}\text { Sep 3, 2000- } \\
\text { Sep 26, } 2000\end{array}$ \\
\hline
\end{tabular}




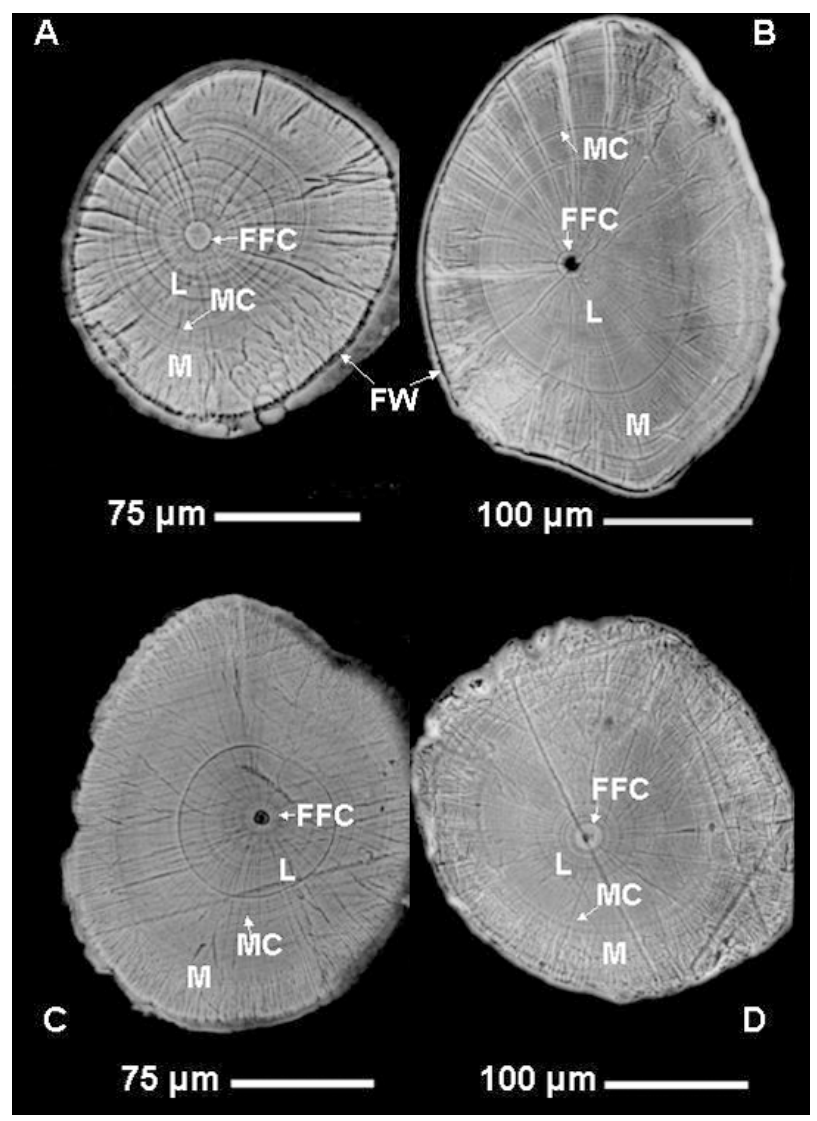

Fig. 5. Anguilla spp. Otoliths sections of (A) A. bicolor bicolor, (B) A. marmorata, (C) A. mossambica and (D) A. nebulosa labiata. FFC: first feed check; L: leptocephalus state; M: metamorphosis stage; MC: metamorphosis check, FW: freshwater check

$\mathrm{p}<0.001$; paired $t$-test, $\mathrm{p}<0.001)$. Conversely, the duration of its metamorphosis stage was significantly longer (33.6 $\pm 7.5 \mathrm{~d})$ than those of A. marmorata (23.3 \pm $4.5 \mathrm{~d})$ and $A$. mossambica $(21.5 \pm 4.5 \mathrm{~d})(\mathrm{K}-\mathrm{W}, \mathrm{p}<0.001$; paired $t$-test, $\mathrm{p}<0.001)$. A. marmorata and A. mossambica were the same age at recruitment and displayed the same leptocephalus and metamorphosis stage length (K-W, $\mathrm{p}<0.05$ in each case). A. nebulosa labiata seemed to have the longest oceanic early life, the 2 specimens collected being 143 and $145 \mathrm{~d}$ old at recruitment. However, the sample was too small to be representative. Nevertheless, the lengths of the leptocephalus and metamorphosis stages of $A$. nebulosa labiata (117.5 \pm 3.5 and $26.5 \pm 2.1 \mathrm{~d}$ respectively) were similar to those of A. marmorata and A. mossambica. Significant and positive linear correlations between age at recruitment and age at metamorphosis occurred in A. marmorata and A. mossambica (Fig. 6, correlation $\mathrm{p}<0.001)$, in contrast to $A$. bicolor bicolor ( $\mathrm{p}>0.05)$.

Otolith growth rate during the leptocephalus stage was significantly higher in Anguilla bicolor bicolor (0.9 $\pm 0.2 \mu \mathrm{m} \mathrm{d}^{-1}$ ) than for A. marmorata and A. mossambica $\left(0.7 \pm 0.1 \mu \mathrm{m} \mathrm{d}^{-1} ; \mathrm{K}-\mathrm{W}, \mathrm{p}<0.001\right.$ and paired $t$-test, $\mathrm{p}<0.01)$. Conversely, at the metamorphosis stage, no significant growth rate differences occurred between the species $\left(2.0 \pm 0.5\right.$ to $\left.2.4 \pm 0.5 \mu \mathrm{m} \mathrm{d}^{-1} ; \mathrm{K}-\mathrm{W}, \mathrm{p}<0.05\right)$. According to its age at recruitment and the length of its freshwater life, A. mossambica hatched 2 mo earlier (July to October) than A. bicolor bicolor (September to January) and A. marmorata (September to December; Table 2).

\section{DISCUSSION}

Glass eels have been described for the first time for Réunion Island: 4 species recruited into Roches River that accorded with the subadults stages described by Marquet et al. (1997) and Keith et al. (1999). Anguilla marmorata and A. bicolor bicolor exhibit clearly differ-

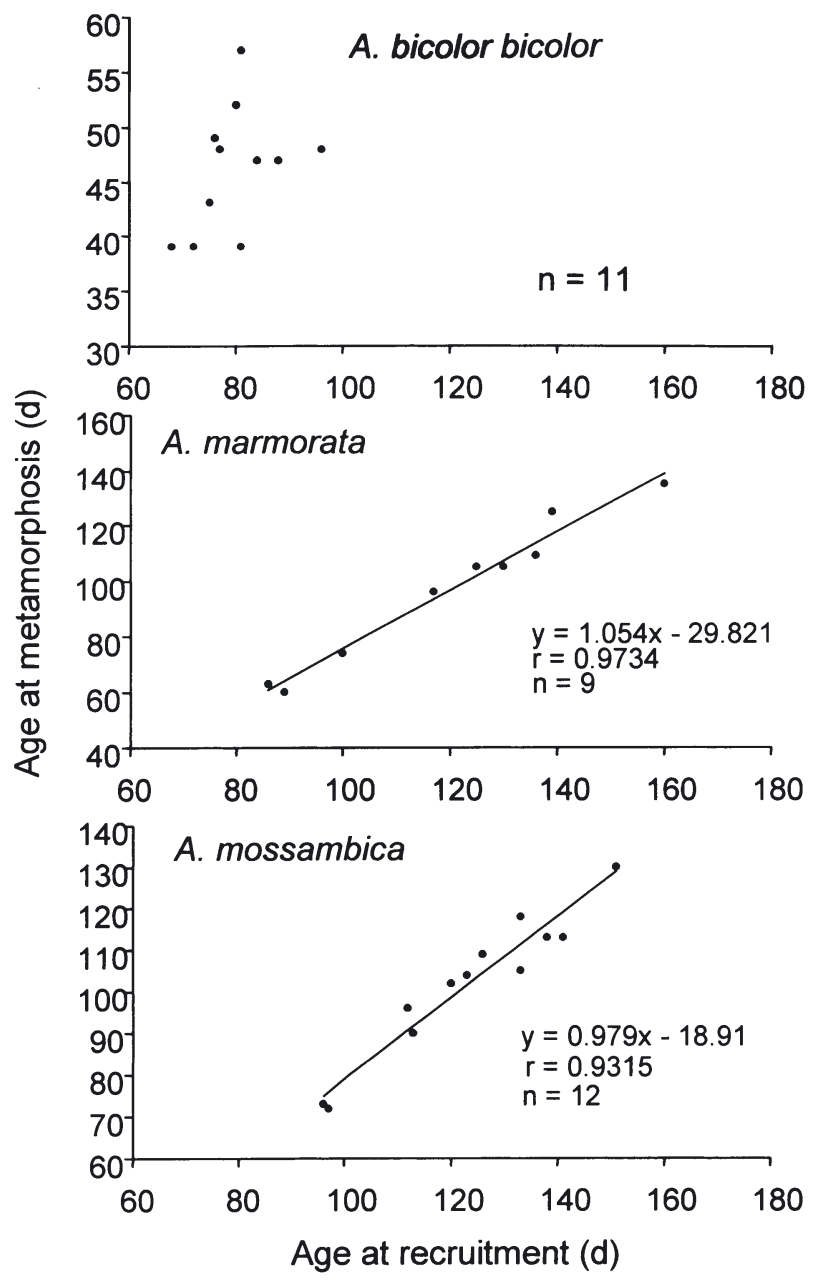

Fig. 6. Anguilla spp. Linear correlations between age at recruitment and age at metamorphosis for tropical eels in Réunion Island 
Table 3. Anguilla spp. Present data on the 4 Indian eels from literature and from present study

\begin{tabular}{|c|c|c|c|c|}
\hline \multirow{2}{*}{$\begin{array}{r}\text { Species } \\
\text { Area }\end{array}$} & \multirow{2}{*}{ Site } & \multicolumn{2}{|c|}{$\mathrm{TL}(\mathrm{mm})$} & \multirow[t]{2}{*}{ Source } \\
\hline & & Mean $\pm \mathrm{SD}$ & Range & \\
\hline \multicolumn{5}{|c|}{ Anguilla marmorata (recruitment: year-round, peaks in Jan-Mar) } \\
\hline Japan & Tanegashima & $49.2 \pm 1.9$ & $45.1-54.2$ & Arai et al. (2002) \\
\hline \multirow[t]{3}{*}{ Taiwan } & Tung-Kan & $50.3 \pm 1.6$ & $48.0-53.4$ & Arai et al. (2002) \\
\hline & Shuang Hsi & $46.9 \pm 0.8$ & $40.0-52.0$ & Budimawan (1997) \\
\hline & Tanshui & $47.3 \pm 0.8$ & $43.0-53.0$ & Budimawan (1997) \\
\hline \multirow[t]{2}{*}{ Philippines } & Cagayan & $49.9 \pm 1.4$ & $47.2-51.6$ & Arai et al. (2002) \\
\hline & Cagayan & 51.22 & $47.0-57.0$ & Tabeta et al. (1976) \\
\hline \multirow[t]{4}{*}{ Indonesia } & Dumoga & $50.9 \pm 2.0$ & $47.9-54.8$ & Arai et al. (2002) \\
\hline & Poigar & $51.2 \pm 1.5$ & $48.2-53.8$ & Arai et al. (2002) \\
\hline & Poso & $51.8 \pm 0.1$ & $48.0-53.0$ & Budimawan (1997) \\
\hline & Poigar & - & $47.0-57.0$ & Sugeha et al. (2001a) \\
\hline \multirow{2}{*}{ French Polynesia } & Hamuta & - & $47.0-57.0$ & Marquet (1992) \\
\hline & Hamuta & $51.5 \pm 3.3$ & $46.0-60.0$ & Budimawan (1997) \\
\hline Réunion & Roches & $53.3 \pm 2.5$ & $45.5-58.5$ & Present study \\
\hline \multicolumn{5}{|c|}{ Anguilla bicolor bicolor (recruitment: Jan-Mar) } \\
\hline \multirow[t]{2}{*}{ Indonesia } & Cimandiri & $52.9 \pm 2.1$ & $43.0-58.0$ & Budimawan (1997) \\
\hline & Cimandiri & $49.4 \pm 2.4$ & $45.5-52.3$ & Arai et al. (1999a) \\
\hline Réunion & Roches & $54.0 \pm 2.1$ & $48.0-59.0$ & Present study \\
\hline \multicolumn{5}{|c|}{ Anguilla mossambica (recruitment: Nov-Dec) } \\
\hline \multirow[t]{2}{*}{ South Africa } & & - & $41.3-54.9$ & Bruton et al. (1987) \\
\hline & & - & $48.0-53.0$ & Jubb (1961) \\
\hline Réunion & Roches & $51.2 \pm 2.7$ & $40.5-57.0$ & Present study \\
\hline \multicolumn{5}{|c|}{ Anguilla nebulosa labiata (recruitment: Jan-Mar) } \\
\hline \multirow[t]{2}{*}{ South Africa } & & - & $50.0-61.5$ & Frost (1957) \\
\hline & & - & $54.0-58.0$ & Jubb (1964) \\
\hline Réunion & Roches & $51.7 \pm 1.1$ & $51.0-52.5$ & Present study \\
\hline
\end{tabular}

ent patterns of cutaneous pigmentation in the caudal region. Moreover in A. bicolor bicolor, the dorsal fin originates just above the origin of the anal fin, a criterion that is valid for the glass eel stage also. A. mossambica and $A$. nebulosa labiata have the same pattern of cutaneous pigmentation in the caudal region, but can be distinguished by their different numbers of vertebrae. Thus, at Réunion Island, morphological characters enable differentiation of at least 2 species, A. marmorata and A. bicolor bicolor. In the remaining 2 species, as in Indonesia, one of the most important distinguishing characteristics is the number of ano-dorsal vertebrae (Sugeha et al. 2001a).

\section{Recruitment patterns}

In the present study, Anguilla marmorata largely dominates numerically the glass eels recruitment in the Roches River, followed by A. mossambica and $A$. bicolor bicolor. A. mossambica dominated numerically in November and December, suggesting an earlier recruitment than the other 2 species, which arrived simultaneously from November to April. A. marmorata is dominant from January to April. Analysis of pigmentation stages showed that most of the glass eels were slightly pigmented (VA + VB + VIA0 + VIA1 $=94 \%$ of the total specimens). This indicates a relatively short estuarine life before entering the river. Nevertheless, A. marmorata glass eels were more pigmented than $A$. bicolor bicolor, despite their simultaneous entry into freshwater. Also, A. mossambica glass eels were more pigmented than A. marmorata individuals. These facts suggest that these species spend different periods of time in coastal waters before entry into inland waters, perhaps timing their arrivals to coincide with conditions optimum for each species.

The relative recruitment ot the 3 species varies considerably among areas. Glass eels of Anguilla bicolor bicolor, A. nebulosa labiata, and A. mossambica reach the rivers of the eastern coast of Africa from January to February; glass eels of the first 2 species occur preferentially north of Latitude $20^{\circ} \mathrm{S}$, and those of the latter species between 21 and $31^{\circ} \mathrm{S}$ (Jubb 1964). Glass eels of A. bicolor bicolor, A. marmorata and A. mossambica reach the coast of Madagascar from January to March (Ege 1939), as at Réunion Island. The glass eels recruiting to South Africa rivers (Natal Province, Bruton et al. 1987) are dominated by A. mossambica (86\%), with $A$. marmorata comprising $9.7 \%$, A. nebulosa labiata $3.7 \%$ and $A$. bicolor bicolor $0.6 \%$. A. marmorata, distributed in the Indo-Pacific area, are the second most abundant glass eels in the Cagayan estuary (Philippines) and in Indonesian estuaries (Tabeta et al. 1976, Sugeha et al. 
2001a). According to available data, insular recruitment of $A$. marmorata occurs throughout the year in its Pacific distribution area (Marquet \& Lamarque 1986, Marquet 1987, Arai et al. 1999b), with different seasonal peaks occurring locally in response to regional hydroclimatic conditions. In Indonesia and the Philippines, A. marmorata recruitment peaks in February to March (Tabeta et al. 1976, Budimawan 1997, Arai et al. 2002), while in French Polynesia 2 annual peaks occur, 1 in January to February and 1 in March to April (Marquet 1992). In North Sulawesi, the Celebes Sea, recruitment peaks in January and May to June, preferentially at new moon (Sugeha et al. 2001a). At Réunion Island (this study), fishermen collect glass eels together with goby-fry during the entire traditional fishing period from November to April. Thereafter, glass eels are not collected until the new moons in the following May to October. Thus, on the basis of our 1 yr study, we conclude that the recruitment period at Réunion Island is likely to occur during the wet season, which usually lasts from January to March. As described for other species and other locations, wet seasons provide favorable recruitment conditions (freshwater runoff). Nevertheless, inter-annual and/or inter-catchment variability in glass-eel recruitment remain undocumented for the Mascarene area.

Glass eels of Anguilla bicolor bicolor, A. marmorata and A. mossambica were larger at recruitment in Réunion Island than in other areas (Table 3), and there were larger size variations in A. marmorata (45.5 to $58.5 \mathrm{~mm}$ ) and A. mossambica (40.5 to $57.0 \mathrm{~mm}$ ) than at other locations. As time to metamorphosis varies in both species, this size variation could arise from environmental heterogeneity in the spawning grounds and related growth conditions. Similarly, A. bicolor bicolor sizes reported for Cimandiri River, Indonesia (45.5 to $52.3 \mathrm{~mm}$ : Arai et al. 1999a), are markedly lower than those found for this species at Réunion Island (48.0 to $59.0 \mathrm{~mm}$ ), possibly because of the shorter duration of the metamorphosis stage in Indonesian glass eels (18 \pm $4.2 \mathrm{~d}$; Arai et al. 1999a). However, all these tropical glass eels are distinctly smaller than temperate species at recruitment (A. japonica, A. Anguilla, A. rostrata, A. australis and $A$. dieffenbachii: Tesch 1977, Tsukamoto 1990, Chisnall et al. 2002). Tropical species may recruit faster after metamorphosis than temperate species.

\section{Early life histories}

Ege (1939) collected leptocephali of Anguilla bicolor bicolor above oceanic trenches around Sumatra and Madagascar. He concluded that one of the spawning areas of this subspecies was located nearby the abyssal trenches off the western coast of Sumatra, where the smallest leptocephali (<20 mm) occurred (Jespersen 1942, Arai et al. 1999a). Given that the smallest leptocephali occurring near Madagascar measured $45 \mathrm{~mm}$ and that their size increased westward, the spawning area for A. bicolor bicolor was thought to be located somewhere in the eastern waters of Madagascar (10 to $20^{\circ} \mathrm{S}, 60$ to $65^{\circ} \mathrm{E}$ : Jespersen 1942, Jubb 1961). This hypothetical sole large spawning ground was also considered to be used by other species of the western Indian Ocean (Jespersen 1942, Jubb 1961). No studies have been conducted to validate this presumed spawning ground. However, the hypothesis is very likely in the light of recent studies on the oceanic circulation of deep and shallow warm water masses (Schott \& McCreary 2001). Moreover, the distribution of inland populations in the western area indicates that these SW Indian Ocean eels are distributed all along the coasts bathed by the South Equatorial Current (SEC). The SEC is a large oceanic current (Schott \& McCreary 2001), oriented westward between Latitudes 12 and $25^{\circ} \mathrm{S}$, and dividing at about $17^{\circ} \mathrm{S}$ into the NE and SE Madagascar Currents around the Mascarene Ridge, along which seamounts (50 m depth) join the Seychelles $\left(4^{\circ} \mathrm{S}, 55^{\circ} \mathrm{E}\right)$ to Réunion Island $\left(21^{\circ} \mathrm{S}, 56^{\circ} \mathrm{E}\right)$. Upwelling cold wedges flow in from the south. There is no evidence for the existence of a southern spawning ground with a migration driven by upwelling currents, since the continental distribution, relatively colder water, and the absence of oceanic ridges do not support this. Réunion Island lies directly in the path of the SEC, which approaches the eastern coast from the southwest. The early life histories of glass eels collected in the Roches River are of interest. Recruitment of A. mossambica glass eels to Réunion Island occurs 2 mo earlier than in A. marmorata, with a similar time lag between hatching dates. Leptocephalus and metamorphosis stage lengths are similar in the 2 species. We hypothesize that A. marmorata and $A$. mossambica are transported by the same oceanic current, and it would thus be reasonable to suggest that both species use the same or adjoining spawning grounds in the Indian Ocean. This would be analogous to $A$. australis recruitment patterns in East Australia, where 2 groups of glass eels invade rivers at 2 different periods of the year. The time lags between the respective hatching dates and recruitment of the 2 groups are similar, and there is a single spawning ground (Shiao et al. 2001). In Java, Indonesia, A. bicolor bicolor glass eels are $177 \pm 16.4 \mathrm{~d}$ old at recruitment (Arai et al. 1999a), almost 3 mo older than glass eels recruiting to Réunion Island $(79.8 \pm 7.7 \mathrm{~d})$. Mean size at recruitment between the east and west sections of the Indian Ocean also differ $(49.4 \pm 2.4$ and $54 \pm$ $2.1 \mathrm{~mm}$ respectively). An eastern spawning ground of this species is strongly presumed to be located in the 
Mentawei deeps in waters west of Sumatra (Jespersen 1942). With its relatively short migration length from arrival at Réunion Island, A. bicolor bicolor must have a western spawning ground in the Indian Ocean close to the Mascarene area, according to Jespersen (1942) and Jubb (1961). A. bicolor bicolor glass eels are notably younger at recruitment in the Roches River $(79.8 \pm 7.7 \mathrm{~d})$ than those of $A$. marmorata and $A$. mossambica $(120.2 \pm 24.7$ and $123.6 \pm 17 \mathrm{~d}$ respectively). This could be due to one of the following facts: (1) this species spawns nearer to Réunion Island than the other species, or (2) it travels faster during its pelagic migration (faster swimming or different migration depths with higher current velocities). However, time to metamorphosis is much longer in $A$. bicolor bicolor ( $33.6 \pm 7.5 \mathrm{~d}$ ) than in the other species from the Roches River. We suggest therefore that its migration route must be different from that of the other species.

The findings of this study confirm the presence of 4 glass eels species recruiting to Réunion Island, with Anguilla marmorata being the most abundant. Age at recruitment and hatching dates were determined from otolith microstructure and local larval migration routes proposed. This study is indicative, not quantitative, and further sampling is needed in this oceanic region to determine the variations in species composition and timing of recruitment, particularly as regards the effect of regional marine currents. More precisely, examination of additional otoliths of glass eels from the vicinity of Réunion Island and from Mauritius to the Rodrigues Islands is necessary to determine the approximate location of the spawning grounds of A. marmorata, $A$. mossambica and A. bicolor bicolor in this area. Moreover, a sampling series of glass eels off the eastern coast of Madagascar, the Comoros Islands or the East African coast would help to clarify the question of a single or of multiple spawning areas of anguillid eels in the western Indian Ocean.

Acknowledgements. This study was supported by the ECOFOR Program of the French Environment Ministry (coordinated by the ARDA). We want to warmly thank Sylvie Guyet, the Bichiques Fishermen's Association of Roches River (and in particular Mr. Thierry Ramjane) for their very useful help during sampling, Dr. Andrew Coward, and Dr. Dimitri Gorand (Université de Perpignan) for SEM assistance.

\section{LITERATURE CITED}

Arai T, Limbong D, Otake T, Tsukamoto K (1999a) Metamorphosis and inshore migration of tropical eels Anguilla spp. in the Indo-Pacific. Mar Ecol Prog Ser 182:283-293

Arai T, Aoyama J, Limbong D, Tsukamoto K (1999b) Species composition and inshore migration of the tropical eels Anguilla spp. recruiting to the estuary of the Poigar River, Sulawesi Island. Mar Ecol Prog Ser 188:299-303

Arai T, Limbong D, Tsukamoto K (2000) Validation of otolith daily increments in the tropical eel Anguilla celebesensis. Can J Zool 78:1078-1084

Arai T, Marui M, Miller MJ, Tsukamoto K (2002) Growth history and inshore migration of the tropical eel, Anguilla marmorata, in the Pacific. Mar Biol 140:309-316

Bruton MN, Bok AH, Davies MTT (1987) Life history styles of diadromous fishes in inland waters of southern Africa. Am Fish Soc Symp 1:104-121

Budimawan (1997) The early life history of the tropical eel Anguilla marmorata (Quoy \& Gaimard, 1824) from four Pacific estuaries, as revealed from otolith microstructural analyses. J Appl Ichthyol 13:57-62

Castle PHJ (1984) Anguillidae. In: Daget J, Grosse JP, Thys van den Audenaerde DFE (eds) Check-list of freshwater fishes of Africa (CLOFFA), Vol 1. ORSTOM, Paris, p 34-37

Castle PHJ (1986) Anguillidae. In: Smith MM, Heemstra PC (eds) Smiths' sea fishes. Springer-Verlag, Heidelberg, p 160-161

Castle PHJ, Williamson GR (1974) On the validity of the freshwater eel species Anguilla ancestralis Ege from Celebes. Copeia 2:569-570

Castonguay M (1987) Growth of American and European eel leptocephali as revealed by otolith microstructure. Can J Zool 65:875-878

Chisnall BL, Jellyman DJ, Bonnett ML, Sykes JR (2002) Spatial and temporal variability in length of glass eels (Anguilla spp.) in New Zealand. NZ J Mar Freshw Res 36: 89-104

Ege V (1939) A revision of the genus Anguilla Shaw: a systematic, phylogenetic and geographical study. Dana Rep 16

Elie P, Lecomte-Finiger R, Cantrelle I, Charlon R (1982) Définition des limites des différents stades pigmentaires durant la phase civelle d'Anguilla anguilla L. (poisson téléostéen anguilliforme). Vie Milieu 32:149-157

Frost WE (1957) First record of the elver of the African eel Anguilla nebulosa labiata Peters. Nature 179:594

Jellyman DJ (1987) Review of the marine life history of Australasian temperate species of Anguilla. Am Fish Soc Symp 1:276-285

Jespersen P (1942) Indo-Pacific leptocephalids of the genus Anguilla: systematic and biological studies. Dana Rep 22:1-128

Jubb RA (1961) The freshwater eels (Anguilla spp.) of southern Africa: an introduction to their identification and biology. Ann Cape Prov Mus Nat Hist 1:15-48

Jubb RA (1964) The eels of South African rivers and observations on their ecology. Monogr Biol 14:186-205

Keith P, Vigneux E, Bosc P (1999) Atlas des poissons et des crustacés d'eau douce de la Réunion. Patrimoines Nat 39: $1-136$

Kruskal WH, Wallis WA (1952) Use of ranks in one-criterion variance analysis. J Am Stat Assoc 47:583-621

Lecomte-Finiger R (1992) Growth history and age at recruitment of European glass eels (Anguilla anguilla) as revealed by otolith microstructure. Mar Biol 114:205-210

Lecomte-Finiger R (1994) The early life of the European eel. Nature 370:424

Marquet G (1987) Périlogie des anguilles de Tahiti-Moorea en Polynésie Française. PhD thesis, Ecole Pratique des Hautes Etudes, Paris

Marquet G (1992) L'étude du recrutement et de la physiologie des anguilles de Polynésie Française permet-elle de cerner leur aire de ponte? Bull Inst Océanogr 10:129-147

Marquet G, Galzin R (1991) The eels of French Polynesia: taxonomy, distribution and biomass. Mer 29:8-17

Marquet G, Lamarque P (1986) Acquisitions récentes sur la 
biologie des anguilles de Tahiti et de Moorea (Polynésie française): A. marmorata, A. megastoma, A. obscura. Vie Milieu 36:311-315

Marquet G, Séret B, Lecomte-Finiger R (1997) Inventaires comparés des poissons des eaux intérieures de trois îles océaniques tropicales de l'Indo-Pacifique (La Réunion, La Nouvelle-Calédonie et Tahiti). Cybium 21(Suppl 1):27-34

Nishi G, Imai S (1969) On the juvenile of Anguilla marmorata Quoy and Gaimard in Yakushima (Yaku Island). Its ecology and morphology. Mem Fac Fish Kagoshima Univ 18: 65-76

Schott FA, McCreary JP Jr (2001) The monsoon circulation of the Indian Ocean. Prog Oceanogr 51:1-123

Shiao JC, Tzeng WN, Collins A, Jellyman DJ (2001) Dispersal pattern of glass eel stage of Anguilla australis revealed by otolith growth increments. Mar Ecol Prog Ser 219:241-250

Sokal RR, Rohlf FJ (1981) Biometry: the principles and practice of statistics in biological research, 2nd edn. WH Freeman, NewYork

Sugeha HY, Arai T, Miller MJ, Limbong D, Tsukamoto K (2001a) Inshore migration of the tropical eels Anguilla spp. recruiting to the Poigar River estuary on north Sulawesi Island. Mar Ecol Prog Ser 221:233-243

Sugeha HY, Shinoda A, Marui M, Arai T, Tsukamoto K (2001b) Validation of otolith increments in the tropical eel Anguilla marmorata. Mar Ecol Prog Ser 220:291-294

Tabeta O, Tanimoto T, Takai T, Matsui I, Imamura T (1976)

Editorial responsibility: Otto Kinne (Editor),

Oldendorf/Luhe, Germany
Seasonal occurrence of anguillid elvers in Cagayan River, Luzon Island, the Phillipines. Bull Jpn Soc Sci Fish 42: $421-426$

Tabeta O, Tanaka K, Yamada J, Tzeng WN (1987) Aspects of the early life history of the Japanese eel Anguilla japonica determined from otolith microstructure. Bull Jpn Soc Sci Fish 53:1727-1734

Tesch FW (1977) The eel: biology and management of anguillid eels. Chapman \& Hall, London

Tsukamoto K (1990) Recruitment mechanism of the eel, Anguilla japonica, to the Japanese coast. J Fish Biol 36: $659-671$

Tsukamoto K, Umezawa A (1990) Early life history and oceanic migration of the eel, Anguilla japonica. Mer 28: 188-198

Tzeng WN, Tsai YC (1992) Otolith microstructure and daily age of Anguilla japonica, Temminck \& Schlegel elvers from estuaries of Taiwan with reference to unit stock and larval migration. J Fish Biol 40:845-857

Umezawa A, Tsukamoto K, Tabeta O, Yamakawa H (1989) Daily growth increments in the larval otolith of Japanese eel, Anguilla japonica. Jpn J Ichthyol 35:440-443

van Someren V, Whitehead P (1959) Records of young eels in Kenya rivers. Nature 183:950-951

Williamson GR, Boëtius J (1993) The eels Anguilla marmorata and A. Japonica in the Pearl River, China, and Hong Kong. Asian Fish Sci 6:129-138

Submitted: July 5, 2002; Accepted: May 8, 2003

Proofs received from author(s): August 27, 2003 